\title{
当院における鏡視下膝半月部分切除術の検討
}

\author{
医療法人玄真堂 川嶌整形外科病院 \\ 田村裕昭・川嶌畺人 \\ 佐々木誠人・多田勝弘
}

\section{Clinical Results of Arthroscopic Partial Meniscectomy}

by

\author{
Hiroaki Tamura, Mahito Kawashima, Makoto Sasaki and Katuhiro Tada \\ Kawashima Orthopedic Hospital
}

\begin{abstract}
Postoperative results of 59 menisci in 58 cases treated by arthroscopic partial meniscectomy were reported. The follow up period ranged from 3 to 43 months (mean, 13 months). Ninety-four percent had excellent and good results subjectively. Clinical scores by Kurosawa knee scoreing scale were $7.5 ; 8.4$ in the non-osteoarthritic knees and 7 in the osteoarthritic knees. Twenty-eight cases among the 58 had osteoarthritic changes and the results of their subjective estimation and the clinical score were almost good. We thought that arthroscopic partial meniscectomy should be considered even for old patients, if chosen with care.
\end{abstract}

\section{は じめに}

膝半月板損傷に对する鏡視下切除術は，近年目党ま しく普及してきたが, 本法の利点としては, 手術侵襲 の軽減, 半月板機能の温存, 後療法の短縮等があげら れよう”. 当院においても最近ではできるだけ鏡視下に 行うことに努め, 現在まで58例の鏡視下部分切除術を 行ってきた，術後短期間ではあるが,これらの症例を 調査し若干の検討を加えたので報告したい。

\section{対 象 症 例}

1985年以来, 58 膝, 59 半月に鏡視下部分切除術を行っ た. 男性 29 例, 女性29例で, 年秢は12 74才, 平均 44.3 才であり, 右膝 27 例, 左滕31例で, 内側半月 39 例, 外 側半月 20 例であった．不完全円板状半月の断裂は 5 例 で，陳旧性前十字勒帯損傷合併例は 6 例，そのうち 3 例には前十字勒帯再建術を同時に行った。断裂側の関 節軟骨に変化の見られた症例は28例で，同時に脛骨高 位骨切り術を行ったのは 4 症例であった。経過観察期 間は 3 力月から 43 力月, 平均 13.0 力月であった. 切除 様式は, 原則として必要最小限の切除とし, 部分切除 52 例, 亜全摘 7 例で, one piece として切除された
ものが10例で, 49例は piece by piece に切除した （表 1 ）。断裂形式は表 2 のごとくであったが，断裂形 式の分類は主要病巣と判断された変化につきおこなっ たが, 主要病巣切除後に他の小断裂（主として水平断 裂）が認められた例も少なくなかった．軟骨病变を有 する症例は, 变性断裂 $(10 / 10)$, 複合断裂 $(5 / 7)$, 水平断裂 $(4 / 7)$ に高率に認められた（表 2$)$. 軟骨 病変は主として大腿骨側の関節面変化に注目して検討 したところ, 線維化 10 例, びらん 5 例, 潰瘍形成 5 例, 象牙質化 2 例であった.

\section{手 術 方 法}

原則として腰椎麻酔下に関節鏡を行い，引き続いて 鏡視下切除術を行った。関節鏡はストルツ社製 $30^{\circ}$ 斜 視鏡を主として用い, 手術器具はプローブ, 鏡視下用 鋏, バスケット鉗子, 把持鉗子, ロータリーパンチ等 を用い，全例ビデオモニターシステム下にて行った。 穿刺は主として溙蓋下内外側の 2 点法にて行い, one piece にて切除するときには 3 点法とし症例に応じて 他の刺入点を追加した．軟骨病変に対しては shaving や drilling 等は行わず，大きな剝離軟骨片のある場合 その切除のみを行った。 
結

果

術後成績は，直接検診及びアンケートの解答によっ て得られた 49 症例に対し，自覚的満足度と黒沢等の評 価基準を用い行った ${ }^{2 !}$. 軟骨病変の有無は術後点数に 影響すると考えられたので，軟骨病変の有無によって も評価を検討した。

自覚的評価では，大変満足が 27 例 $46.0 \%$ ，満足 28 例 $48.0 \%$ ，不満足 3 例 $6.0 \%$ であった．軟骨病変の有無 での自覚的評価では図 1 のごとく, 軟骨病変の無い群 で半数が大変満足と解答し軟骨病変の有る群より勝っ

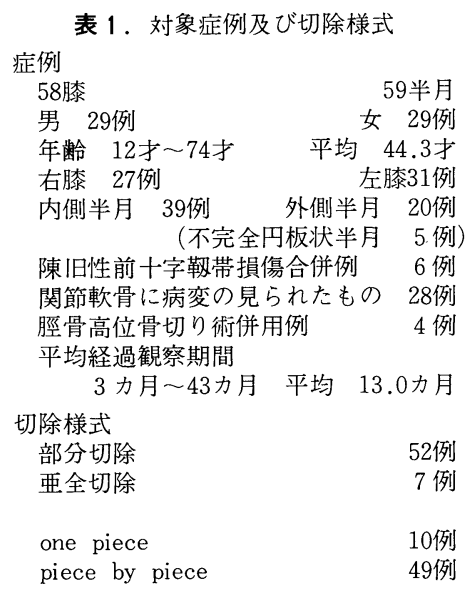

術前・術後の評価点の推移

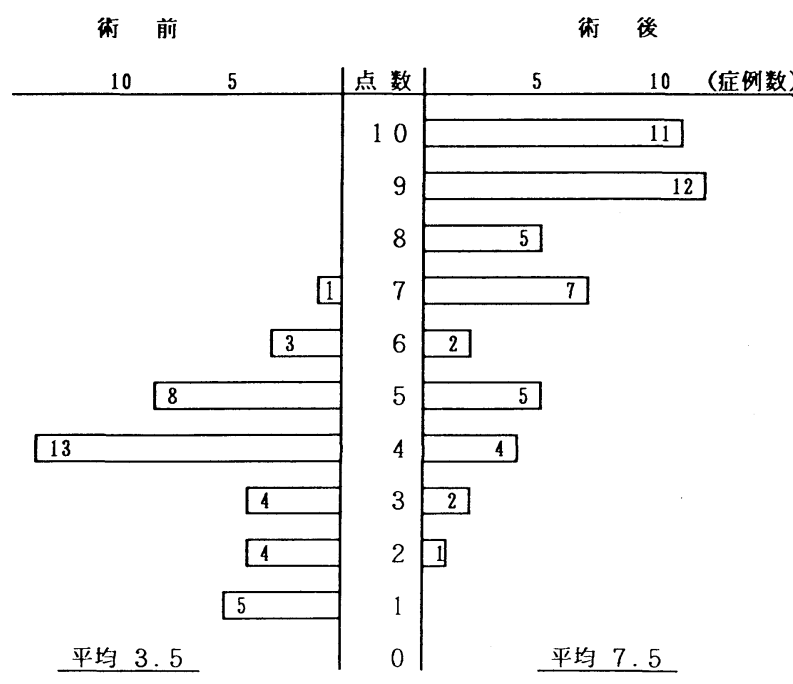

ていた（図 1 ).

黒沢評価点では, 術前平均 3.5 点から 7.5 点へ改善し,

表2. 半月板の断裂形式

\begin{tabular}{|c|c|c|c|}
\hline 断裂形式 & 内側例 & 外側例 & 症例総数 \\
\hline バケツ柄 & $3(1)$ & & $3(1)$ \\
\hline 縦 & 3 & 2 & $5(1)$ \\
\hline 水 平 & $7(4)$ & & 7 (4) \\
\hline L 型 & $12(5)$ & 3 & $15(5)$ \\
\hline 横 & $3(3)$ & 9 & $12(3)$ \\
\hline 複 合 & $6(5)$ & 1 & $7(5)$ \\
\hline 変 性 & $5(5)$ & $5(5)$ & $10(10)$ \\
\hline 計 & 39 (23) & $20(5)$ & 59 (28) \\
\hline
\end{tabular}

（）内は軟骨病変 $\oplus$

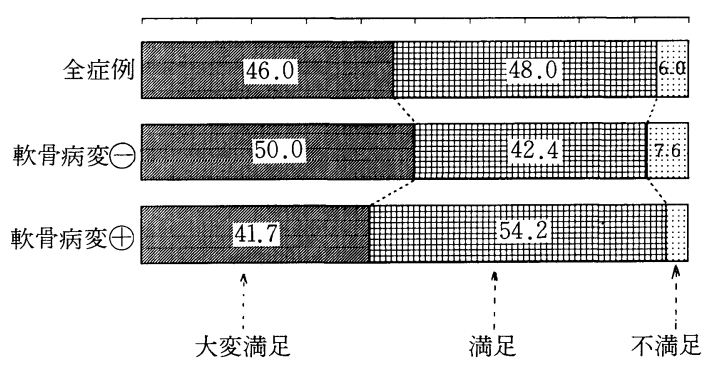

図 1. 自賞的評価

術前・術後の

平均評価点の推移

図 2. 術前・術後の黒沢評価点の推移

$$
-23-
$$


軟骨病変の無い群で 4 点から8.4点へ, 軟骨病変の有 る群では2.9点から7点へ改善していた（図2）.

自賞的に不満足と答えた 3 症例は他党的にも改善が 得られず半月症状が残存した。このうち 2 症例は， 3 力月後と 14 力月にそれぞれ関節切開にて全摘出し, 残 クの 1 症例は経過観察中である.

\section{考察}

鏡視下手術の成否は，熟練した技術，適切な手術器 具の選択，適切な穿刺部位，症例の正しい選択による と考えられる。

技術修得にはある程度の経験が必要となるが，ビデオ モニターシステムの使用は技術修得促進に有効な方法 であった。

内側の中後節移行部や前節から前角にかけての切除 は困難を伴うことが多いがここのような部位での手術 器具の選択は重要で, 関節切開による再手術を余儀な くされた症例のうちの一例は外側半月前節での複合断 裂で，通常の手術器具では切除が不十分になりがちな 部位で，現在では先端の $90^{\circ}$ 屈曲したロータリーパンチ を使用することで比較的容易になった．他の再手術の 一例は内側半月の中後節移行部での複合断裂で, 全摘 してみると断裂は外緣部まで及んでおり，切除範囲の 不足が原因と考号られた．現在では，先の細いバス ケットパンチや，切除片を吸引しつつ操作可能なサク ションパンチを用いて必要十分な切除が行えるよう心 がけている.

穿刺部位に関しては黒沢等の詳細な検討の報告があ るが゙，原則的には piece by piece に切除するとき には滕蓋下内外穿刺で行い, one piece として切除す るときは経膝蓋䩚帯穿刺を追加した。しかし，断裂頻 度の高い内側の中後節移行部断裂において, 顆間隆起 が高く, 脛骨内側顆の後傾の強い例や，外側に円盤状 半月を合併している例では，大腿骨内側顆が視野を妨 げ，他の穿刺を併用したり外反ストレスをかけても手 術操作に困難を伴う例があり今後の課題と思われた。

断裂形式による術後評価点の差をみると，縦断裂 (バケツ柄断裂を含む), 横断裂, L字断裂, 水平断裂, 複合断裂，変性断裂の順であった。变性断裂は全例に 軟骨病変を有し, 術後平均 4.9 点と低く, 術前より軟 骨病変の強いことが予想される症例での手術適応決定 には慎重を要すと考えられた（表 3 ).
表 3. 断裂形式別術後成績

\begin{tabular}{|c|c|c|c|c|c|}
\hline \multirow[t]{2}{*}{ 損傷形式 } & \multirow[t]{2}{*}{ 膝 数 } & \multirow[t]{2}{*}{ 術後得点 } & \multicolumn{3}{|c|}{ 自党評価（\%） } \\
\hline & & & 大変満足 & 満 足 & 不渾 足 \\
\hline バケツ柄十縦 & 8 & 9.1 & $6(75)$ & $2(25)$ & \\
\hline L 型 & 13 & 7.8 & $6(46)$ & 7 (54) & \\
\hline 水 平 & 4 & 7.3 & $2(50)$ & $2(50)$ & \\
\hline 横 & 10 & 8.4 & $5(50)$ & $5(50)$ & \\
\hline 複合 & 6 & 6.3 & $2(33)$ & $2(33)$ & $2(33)$ \\
\hline 性 & 8 & 4.9 & $2(25)$ & $5(62)$ & $1(13)$ \\
\hline
\end{tabular}

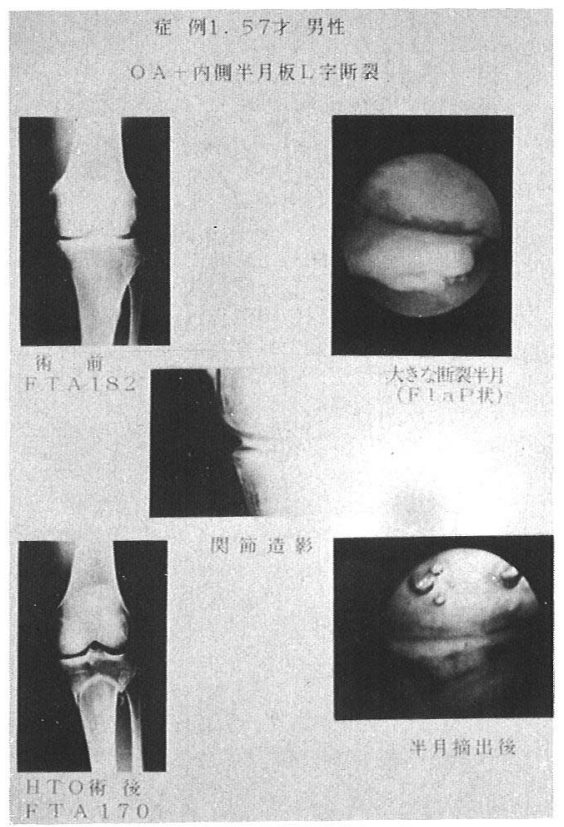

図 3. 鏡視下内側半月板部分切除 十脛骨高位骨切り術施行例

鏡視上軟骨病変を認めたのは28例であったが，この うち内側に病変を認めたのは22例で，これらは単純X線 や造影にて変形性膝関節症が確認され，一例を除き全 例が50才以上であり平均年令は60.8才であった。内側 型変形性滕関節症に対する鏡視下半月切除術について は，症状や変形の程度に応じて適応を慎重に考虑する 必要がある.しかし，高鮯者においては半月板も変性 をきたし断裂しやすくなっており，半月症状による愁 訴の存在も常に考虑しておく必要があると考える．基 本的には, 足底板や筋力訓練等の保存的治療にて経過 観察し，必要があれば関節造影を行い手術適応を検討 


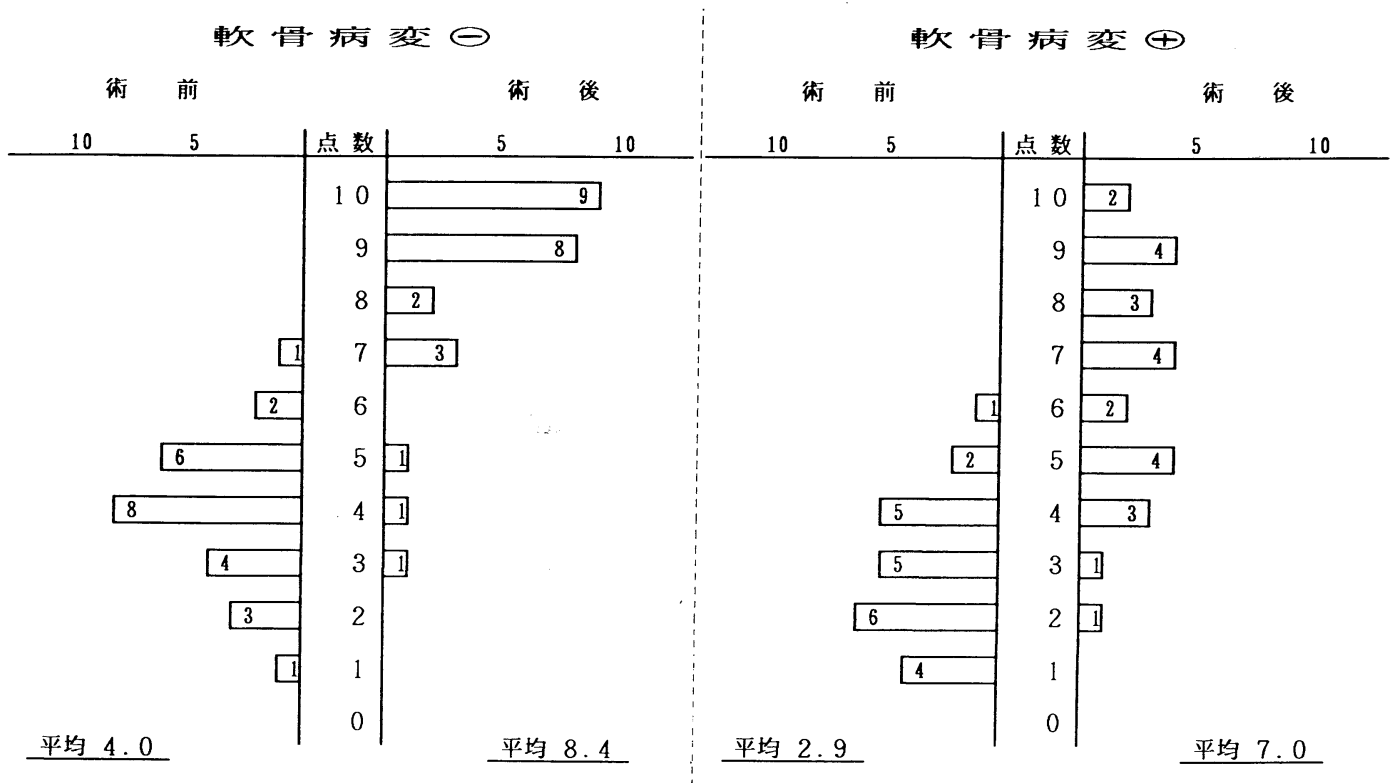

図 4 、軟骨病変の有無による術後評価点の比較

している. 半月症状と変形性膝関節症による症状の区 別は難しい場合も少なくないと考えるが, X線上骨棘 や骨硬化等の初期関節症で, 歩行時急激な疼痛の出現 や locking, 立ち上がり時の強い疼痛等の自覚症状や, Apley や Mcmurry 等の他賞的症状があれば積極的に 半月の鏡視下切除術を行った.このような自他党的所 見に加えて ${ }^{8)}$, 守屋等は立位 FTA $180^{\circ}$ 以下であること ${ }^{51}$ を，奥田等は関節動摇性のないことを手術適応にあげ ている ${ }^{6)}$. 今回, 症例数も少ないため変形の程度と術後 評価の関係についての検討はできないが，X線上明ら かに関節裂隙の狭少化を示した症例でも良好な除痛が 得られた症例もあった.

鏡視所見では，線維化10例，びらん 5 例，潰瘍形成 5 例, 象牙質化 2 例であり，象牙質化の 2 例と潰瘍形 成 5 例中 2 例に半月切除と同時に脛骨高位骨切り術を 行った. 4 症例に同時に脛骨高位骨切り術を行ったが 経過は良好であった。塩見等は脛骨高位骨切り術後に 損傷半月は自然治癒し半月症状は次第に軽減するので, 脛骨高位骨切り術を行う場合は半月機能を最大限温存 する意味で半月切除は極力避けるべきと結論している7!. しかし, 症例 1 のように大き flap 状の断裂片が陷入 するような例では，脛骨高位骨切り術のみでは確実な 除痛が得られるかどうか不明であり，このような例で
はその部の部分切除で術後早期より除痛が得られ有効 と考える(図 3 ).

軟骨病変の有る群では術後平均 7.0 点と軟骨病変の 無い群の 8.4 点に比べて低く, 点数分布のばらつきも 多いが, 平均 4.1 点の改善が得られ比較的満足すべき 結果であった，術後疼痛の残存している例でも，ほと んどが術前に比べて疼痛は軽くなったとの自覚的評価 が得られていた（図４）。

術後経過観察期間も短く症例数も少ないので, 内側 型変形性膝関節症に対する半月の鏡視下切除術の効果 を論ずるには不十分ではあるが，少ない手術侵襲で良 好な結果が得られるとの印象を得たので，今後も症例 を選んで行っていきたい.

\section{ま と め}

1 . 自験例 58 膝 59 半月の鏡視下部分切除術につき検討 した。

2.自覚的評価では，大変満足 $46 \%$, 満足 $48.0 \%$ ，不 満足6.0\%であり, 黒沢評価点では, 術前平均 3.5 点が 7.5点へ改善した.

3 . 鏡視にて軟骨病変の認められた28例の評価点は, 術前平均 2.9 点が 7 点へ改善し, 自覚的満足度も高く, 変形性膝関節症を有する半月障害に対しても適応を選 
んで行えば良好な結果が得られると示唆された。

4. 鏡視下手術の困難な内側の中後節移行部や内外側

の前節付近での損傷では, 先の細いバスケットパンチ,

サクションパンチ，ロータリーパンチ等の使用が有効

であった。

\section{参 考 文 献}

1）木村雅史ほか：関節鏡視下膝半月板切除術の検討. 整形災害外科, 25(8): 1133-1141, 1982.

2) 黒沢 尚ほか：半月板損傷の評価判定について. 膝, $5: 96-98,1979$.

3）黑沢 尚ほか：鏡視下半月切除術における穿刺部位
について。関節鏡, 10(1)：97-101， 1985.

4）三馬正幸ほか：鏡視下半月板切除術の工夫. 関節鏡, 10(1):109-113, 1985.

5）守屋秀繁ほか：変形性膝関節症に対する関節鏡的診 断および鏡視下手術についての考察。関節鏡，12(1)： 173-177, 1987.

6）奥田亮宏ほか：変形性滕関節症における高位脛骨骨 切り術後の半月の変化について. 関節鏡, 12(1): 179183, 1987.

7）塩見俊次ほか：半月板症状が主体の変形性膝関節症 に打ける半月板切除の是非. 関節鏡，4：42-47，1979

8）竹田賢一ほか：高令者に対する膝半月切除術の経験. 関節鏡, 12(1)：193-200, 1987. 